\title{
KAJIAN LITERATUR MODEL PEMBELAJARAN BERMAKNA (MEANINGFUL LEARNING)
}

\author{
Fahmi Hujjatul Islami \\ Pendidikan Fisika \\ Fakultas Keguruan dan Ilmu Pendidikan, Universitas Siliwangi \\ Tasikmalaya, Jawa Barat, Indonesia 46115
}

Email: 182153065@student.unsil.ac.id

\begin{abstract}
Abstrak
Penelitian ini dilatarbelakangi oleh perlunya dilakukan perbaikan pembelajaran yang bermakna tentunya pada prosees pembelajaran di sekolah. Penelitian dilakukan dengan menggunakan metode studi literatur, yang selanjutnya sumber literatur tersebut dikaji lalu dibuat hasil dan pembahasan sehingga dapat dibuat kesimpulan. Pembelajaran bermakna merupakan suatu proses mengaitkan informasi baru pada konsep-konsep relevan yang terdapat dalam struktur kognitif seseorang Struktur kognitif meliputi fakta-fakta, konsep-konsep, dan generalisasigeneralisasi yang telah dipelajari dan diingat siswa. Faktor faktor utama yang mempengaruhi belajar bermakna menurut Ausubel adalah struktur kognitif yang ada, stabilitas dan kejelasan pengetahuan dalam suatu bidang studi tertentu dan pada waktu tertentu.
\end{abstract}

Kata kunci : Pembelajaran Bermakna, Ausubel, Kognitif

Abstract

This research is motivated by the need to make meaningful learning improvements, of course, in the learning process at school. The research was conducted using the literature study method, which was then reviewed and the results and discussions were made so that conclusions could be drawn. Meaningful learning is a process of relating new information to relevant concepts contained in one's cognitive structure. Cognitive structure includes facts, concepts, and generalizations that students have learned and remembered. The main factors that influence meaningful learning according to Ausubel are the existing cognitive structure, stability and clarity of knowledge in a particular field of study and at a certain time.

Keywords: Meaningful Learning, Ausubel, Cognitive 


\section{Pendahuluan}

Pembelajaran bermakna (meaningful learning) merupakan suatu proses mengaitkan informasi baru pada konsep-konsep relevan yang terdapat dalam struktur kognitif seseorang. Menurut Davis (1993), pembelajaran adalah kegiatan aktif proses membangun fenomena yang ada di lingkungan, menghubungkan pengetahuan yang dikuasai dengan pengetahuan yang baru, pengetahuan akan menjadi bermakna ketika ditampilkan dalam beberapa kerangka kerja. Menurut Yekta (2004), strategi pemetaan konsep secara signifikan dapat meningkatkan daya ingat saat belajar dan terciptanya pembelajaran bermakna.

Menurut Ausubel (1978), agar belajar lebih bermakna terjadi dengan baik dibutuhkan beberapa syarat, yaitu: (1) materi yang dipelajari harus bermakna secara potensial, (2) anak mempunyai tujuan belajar bermakna sehingga mempunyai kesiapan dan niat untuk belajar bermakna.

Pemaknaan inilah yang merupakan bentuk inovasi. Melalui pemaknaan, (1) pengajaran sains terintegrasi dengan pendidikan budi pekerti; (2) penyajian konsep / teori tidak berhenti sampai pemahaman konsep saja tapi dimaknai sehingga siswa dapat melihat kaitan apa yang dipelajarinya dengan norma dan situasi kehidupan yang meliputi teknologi, nilai dasar kehidupan, masyarakat dan lingkungan hidup.

Sutikno (2007) menyatakan bahwa pencapaian kualitas pembelajaran merupakan tanggungjawab seorang guru dan dosen melalui penciptaan pengalaman belajar yang bermakna bagi siswa atau mahasiswa dan fasilitas yang didapat siswa atau mahasiswa untuk mencapai hasil belajar yang maksimal.

Pembelajaran bermakna merupakan suatu pendekatan dalam pengelolaan sistem pembelajaran melalui cara-cara belajar yang aktif menuju belajar yang mandiri. Kemampuan belajar mandiri merupakan tujuan akhir dari pembelajaran bermakna. Untuk dapat mencapai hal tersebut, kegiatan perkuliahan dirancang sedemikian rupa agar bermakna bagi mahasiswa. Belajar bermakna terjadi bila mahasiswa berperan aktif dalam proses belajar dan akhirnya mampu memutuskan apa yang akan dipelajari dan cara mempelajarinya (Yamin, 2007).

Pembelajaran bermakna berguna untuk menumbuhkan kemampuan belajar aktif pada diri mahasiswa dan menggali kemampuan mahasiswa serta dosen untuk bersama sama berkembang dalam berbagai pengetahuan keterampilan dan pengalaman. Melalui belajar bermakna mahasiswa diharapkan akan lebih mampu mengenal dan mengembangkan semua 
pengetahuan yang dimilikinya. Di samping itu, mahasiswa juga secara penuh menyadari akan pentingnya menggunakan berbagai sumber belajar yang terdapat di sekelilingnya, mendorong mahasiswa untuk berprakarsa, berpikir secara sistematis, kritis, tanggap, sehingga dapat menyelesaikan masalah dalam kehidupan sehari-hari melalui pencarian informasi yang berguna bagi dirinya.

Menurut Ausubel dan Novak (Burhanuddin, 1996: 115) ada tiga kebaikan belajar bermakna, yaitu:

1. Informasi yang dipelajari secara bermakna lebih lama diingat

2. Informasi baru yang telah dikaitkan dengan konsep-konsep relevan sebelumnya dapat meningkatkan konsep yang telah dikuasai sebelumnya sehingga memudahkan proses belajar mengajar berikutnya untuk memberi pelajaran yang mirip.

3. Informasi yang pernah dilupakan setelah pernah dikuasai sebelumnya masih meninggalkan bekas sehingga memudahkan proses belajar mengajar untuk materi pelajaran yang mirip walaupun telah lupa.

Pembelajaran bermakna adalah pembelajaran yang menyenangkan yang akan memiliki keunggulan dalam meraup segenap informasi secara utuh sehingga konsekuensi akhir meningkatkan kemampuan siswa. Pembelajaran bermakna merupakan suatu proses dikaitkannya informasi baru padakonsep-konsep relevan yang terdapat dalam struktur kognitif seseorang.

Dengan demikian, agar terjadi belajar bermakna maka guru harus selalu berusaha mengetahui dan menggali konsep-konsep yang telah dimiliki peserta didik dan membantu memadukannya secara harmonis konsep-konsep tersebut dengan pengetahuan baru yang akan diajarkan. Jadi belajar akan lebih bermakna jika anak mengalami langsung apa yang dipelajarinya dengan mengaktifkan lebih banyak indera daripada hanya mendengarkan orang/guru menjelaskan.

Muchlas Samani (2007) mengemukakan bahwa apapun metode pembelajarannya, maka harus bermakna (meaningfull learning). Pembelajaran bermakna merupakan suatu proses mengaitkan informasi baru pada konsep-konsep relevan yang terdapat dalam struktur kognitif seseorang. Struktur kognitif ialah fakta-fakta, konsep-konsep dan generalisasi-generalisasi yang telah dipelajari dan diingat siswa. 
Dari uraian di atas, dapat dipahami bahwa pembelajaran bermakna merupakan suatu proses dikaitkannya informasi baru pada konsep-konsep relevan yang terdapat dalam struktur kognitif siswa yang mengikuti pembelajaran.

\section{Metode Penelitian}

Metode penelitian yang digunakan adalah metode literasi (Studi Pustaka), dengan mengkaji berbagai literature, kemudian disajikan dalam hasil dan pembahasan sehingga dapat dibuat kesimpulan.

\section{Hasil dan Pembahasan}

A. Teori Belajar Bermakna Ausubel

David Ausubel adalah seorang ahli psikologi pendidikan yang terkenal dengan teori belajar bermakna (meaningfull). Ausubel membedakan antara belajar menemukan dengan belajar menerima. Pada belajar menerima siswa hanya menerima, jadi tinggal menghafalkannya, tetapi pada belajar menemukan konsep ditemukan oleh siswa, jadi tidak menerima pelajaran begitu saja.

Menurut Ausubel (Burhanuddin, 1996 : 112) pembelajaran bermakna merupakan suatu proses mengaitkan informasi baru pada konsep-konsep relevan yang terdapat dalam struktur kognitif seseorang. Struktur kognitif meliputi fakta-fakta, konsep-konsep, dan generalisasi-generalisasi yang telah dipelajari dan diingat siswa.

Faktor-faktor utama yang mempengaruhi belajar bermakna menurut Ausubel adalah struktur kognitif yang ada, stabilitas dan kejelasan pengetahuan dalam suatu bidang studi tertentu dan pada waktu tertentu. Pembelajaran bermakna terjadi apabila seseorang belajar dengan mengasosiasikan fenomena baru ke dalam struktur pengetahuan mereka. Dalam proses belajar seseorang mengkonstruksi apa yang telah ia pelajari dan mengasosiasikan pengalaman, fenomena, dan fakta-fakta baru ke dalam struktur pengetahuan mereka.

B. Kebaikan Belajar Bermakna

Menurut Ausubel dan Novak (Burhanuddin, 1996 : 115) ada tiga kebaikan belajar bermakna, yaitu :

1. Informasi yang dipelajari secara bermakna lebih lama diingat.

2. Informasi baru yang telah dikaitkan dengan konsep-konsep relevan sebelumnya dapat meningkatkan konsep yang telah dikuasai sebelumnya 
sehingga memudahkan proses belajar mengajar berikutnya untuk memberi pelajaran yang mirip.

3. Informasi yang pernah dilupakan setelah pernah dikuasai sebelumnya masih meninggalkan bekas sehingga memudahkan proses belajar mengajar untuk materi pelajaran yang mirip walaupun telah lupa.

Prasyarat agar belajar menerima menjadi bermakna menurut Ausubel, yaitu:

1. Belajar menerima yang bermakna hanya akan terjadi apabila siswa memiliki strategi belajar bermakna.

2. Tugas-tugas belajar yang diberikan kepada siswa harus sesuai dengan pengetahuan yang telah dimiliki siswa.

3. Tugas-tugas belajar yang diberikan harus sesuai dengan tahap perkembangan intelektual siswa.

C. Langkah-langkah Pembelajaran Bermakna Menurut Ausubel

1. Menentukan tujuan pembelajaran.

2. Melakukan identifikasi karakteristik siswa (kemampuan awal, motivasi, gaya belajar, dan sebagainya).

3. Memilih materi pelajaran sesuai dengan karakteristik siswa dan mengaturnya dalam bentuk konsep-konsep inti.

4. Menentukan topik-topik dan menampilkannya dalam bentuk advance organizer yang akan dipelajari siswa.

5. Mempelajari konsep-konsep inti tersebut, dan menerapkannya dalam bentuk nyata/konkret.

6. Melakukan penilaian proses dan hasil belajar siswa.

\section{Kesimpulan}

Pembelajaran bermakna merupakan suatu proses mengaitkan informasi baru pada konsep-konsep relevan yang terdapat dalam struktur kognitif seseorang Struktur kognitif meliputi fakta-fakta, konsep-konsep, dan generalisasi-generalisasi yang telah dipelajari dan diingat siswa. Faktorfaktor utama yang mempengaruhi belajar bermakna menurut Ausubel adalah struktur kognitif yang ada, stabilitas dan kejelasan pengetahuan dalam suatu bidang studi tertentu dan pada waktu tertentu. Pembelajaran bermakna terjadi apabila seseorang belajar dengan mengasosiasikan fenomena baru ke dalam struktur pengetahuan mereka. Dalam proses belajar seseorang mengkonstruksi apa yang telah ia pelajari dan 
mengasosiasikan pengalaman, fenomena, dan fakta-faktabaru ke dalam struktur pengetahuan mereka. 


\section{Daftar Pustaka}

Anak Ciremai. 2011. Pengertian Belajar Bermakna. ((Online): http://www.anakciremai.com/2011/11/pengertian-belajar-bermakna.html , diakses tanggal 30 Mei 2021).

Dina Octaria. Teori Belajar Bermakna dari David P Ausubel ((Online): https://dinaoctaria.word press.com/2012/10/15/teori-belajar-bermaknadari-david-p-ausubel/ . Diakses tanggal 30 Mei 2021)

Najib, D. A., \& Elhefni, E. (2016). Pengaruh penerapan pembelajaran bermakna (meaningfull learning) pada pembelajaran tematik IPS terpadu terhadap hasil belajar siswa kelas III di MI Ahliyah IV Palembang. JIP (Jurnal Ilmiah PGMI), 2(1), 19-28.

Rahmah, N. (2013). Belajar Bermakna Ausubel. Al-Khwarizmi: Jurnal Pendidikan Matematika dan Ilmu Pengetahuan Alam, 1(1), 43-48.

Setyo, A. (2011). Pembelajaran bermakna berpendekatan SETS pada pelajaran Biologi untuk menumbuhkan kepedulian terhadap lingkungan. Jurnal Bioma, 1(2), 1-5.

Tarmid zi, T. (2019). Belajar Bermakna (Meaningful Learning) Ausubel Menggunakan Model Pembelajaran dan Evaluasi Peta Konsep (Concept Mapping) Untuk Meningkatkan Kemampuan Pemahaman Konsep Mahasiswa Calon Guru Sekolah Dasar Pada Mata Kuliah Konsep Dasar IPA. Caruban: Jurnal Ilmiah Ilmu Pendidikan Dasar, 1(2), 131-140.

Yogihati, C. I. (2010). Peningkatan Kualitas Pembelajaran Fisika Umum Melalui Pembelajaran Bermakna dengan Menggunakan Peta Konsep. Jurnal Pendidikan Fisika Indonesia, 6(2). 